\title{
PERAN GURU TERHADAP PENGEMBANGAN KARAKTER PERSPEKTIF TASAWUF
}

\author{
1 Puput Rikayatul Qur'ani, 'Sintia Roka'iyah \\ ${ }^{1}$ Institut Agama Islam Negeri Jember, ${ }^{2}$ Institut Agama Islam Negeri Jember \\ 1rikaqurani8@gmail.com, 2sintiarokaiyah@gmail.com
}

\section{ABSTRACT}

Education is important in today's era, including in this era of globalization. Education can shape a person into a quality person. In developing the character of students in schools, teachers have a strategic position as the main actor. The teacher is a figure who can be imitated or become an idol for students. The attitude and behavior of a teacher is very imprinted on students, so that the speech, character and personality of the teacher become a mirror of students. Thus, teachers have a great responsibility in producing a generation of character, culture, and morality. Sufism is an activity of cleansing the soul, filling it with commendable qualities, and getting closer and in the presence of Allah.

\section{ABSTRAK}

Pendidikan merupakan hal yang penting di era globalisasi ini. Pendidikan dapat membentuk seseorang menjadi pribadi yang berkualitas. Dalam mengembangkan karakter siswa di sekolah, guru memiliki posisi strategis sebagai aktor utama. Guru merupakan sosok yang dapat ditiru atau menjadi idola siswa. Sikap dan perilaku seorang guru sangat membekas pada diri siswa, sehingga tutur kata, watak dan kepribadian guru menjadi cerminan siswa.Dengan demikian, guru memiliki tanggung jawab yang besar dalam menghasilkan generasi yang berkarakter, berbudaya, dan berakhlak mulia.Tasawuf adalah kegiatan membersihkan jiwa, mengisinya dengan sifat-sifat yang terpuji, dan mendekatkan diri dan ke hadirat Allah.

\section{ARTICLE HISTORY}

Received 20 Juni 2021

Revised 15 September 2021

Accepted 24 September 2021

\section{KEYWORDS}

Education, teacher's role, character, Sufism 


\section{PENDAHULUAN}

Pendidikan merupakan hal yang penting di zaman sekarang, termasuk di era globalisasi yang berkembang semakin pesat. Pendidikan dapat membentuk seseorang menjadi orang yang berkualitas. Salah satu wadah untuk membentuk manusia agar mempunyai kualitas yang tinggi serta dapat mengembangkan potensi yang ada pada diri seseorang ialah dengan pendidikan. Dalam Undang-Undang Nomor 20 Tahun 2003 tentang Sistem Pendidikan Nasional menjelaskan bahwa pendidikan adalah usaha sadar, terencana untuk mewujudkan suasana belajar dan proses pembelajaran agar peserta didik secara aktif dan mengembangkan potensi dirinya untuk memiliki kekuatan spiritual, keagamaan, pengendalian diri, kepribadian, kecerdasan, akhlak mulia, serta keterampilan yang diperlukan dirinya, atau masyarakat bangsa dan negara. ${ }^{1}$ Tujuan dari pendidikan dijelaskan juga pada UndangUndang Nomor 20 Tahun 2003, tentang Sistem Pendidikan Nasional, pasal 3, bahwa Pendidikan Nasional memiliki tujuan untuk mengembangkan potensi peserta didik agar menjadi manusia yang beriman dan bertakwa kepada Tuhan Yang Maha Esa, memiliki akhlak mulia, berilmu, kreatif, mandiri, dan menjadi warga negara yang demokratis dan tanggung jawab. ${ }^{2}$

Pada masa globalisasi saat ini bangsa kita telah mampu menghasilkan Sumber Daya Manusia yang dari segi kuantitas sudah memadai, namun dari segi kualitas masih sangat perlu ditingkatkan agar menghasilkan SDM yang mampu berkompetisi dengan negara berkembang lainnya, bahkan negara maju. Selain SDM yang demikian, masih ada hal penting yang harus ditekankan, yaitu menghasilkan SDM yang beretika, bermoral, sopan santun, dan mampu berinteraksi dengan masyarakat secara baik, dengan memegang teguh kepribadian bangsa. Dengan kata lain, negara menginginkan terbentuknya generasi yang berkarakter dan berkualitas akhlaknya sekaligus cerdas

\footnotetext{
1 Seketariat Negara RI, Undang-undang No. 20 Tahun 2003, Tentang Sistem Pendidikan Nasional, pasal 1 , ayat 1 .

2 Seketariat Negara RI, Undang-undang No. 20 Tahun 2003, Tentang Sistem Pendidikan Nasional, pasal 3.
} 
intelektualnya. Banyak contoh anak didik yang cerdas, tetapi kualitas akhlaknya kurang, maka mereka tidak dapat diharapkan untuk menjadi generasi penerus yang dapat membangun bangsa kita. ${ }^{3}$

Pengembangan atau pembentukan karakter diyakini perlu dan penting untuk dilakukan oleh sekolah untuk menjadi pijakan dalam penyelenggaraan pendidikan karakter di sekolah. Tujuan pendidikan karakter pada dasarnya adalah mendorong lahirnya anak-anak insan kamil. Tumbuh dan berkembangnya karakter yang baik akan mendorong peserta didik tumbuh dengan kapasitas dan komitmennya untuk melakukan berbagai hal yang terbaik dan melakukan segalanya dengan benar dan memiliki tujuan hidup. Karakter dikembangkan melalui tahap pengetahuan, pelaksanaan, dan kebiasaan. Karakter tidak terbatas pada pengetahuan saja. Seseorang yang memiliki pengetahuan kebaikan belum tentu mampu bertindak sesuai dengan pengetahuannya, jika tidak terlatih untuk melakukan kebaikan tersebut. Karakter juga menjangkau wilayah emosi dan kebiasaan diri. ${ }^{4}$ Karakter juga berarti ciri khas yang dimiliki oleh suatu benda atau individu, ciri khas tersebut adalah asli dan mengakar pada kepribadian benda atau individu tersebut dan merupakan "mesin" pendorong bagaimana seseorang bertindak, bersikap, berkata dan merespon sesuatu. ${ }^{5}$ Saat ini banyak pendidikan yang diarahkan untuk lebih mengarah kepada kemampuan berfikir melalui serangkaian pengetahuan keilmuan untuk meraih materi sebanyak-banyaknya sehingga mengurangi munculnya akhlak mulia. ${ }^{6}$

Sementara itu Guru merupakan suatu profesi, berarti suatu jabatan yang memerlukan keahlian khusus sebagai Guru dan tidak dapat dilakukan oleh

\footnotetext{
${ }^{3}$ Edi Kuswanto, Peranan Guru PAI dalam Pendidikan Akhlak di Sekolah, ttt. ttp. hlm. 203.

4 Akhmad Sudrajat. Pengembangan Karakter. Retrieved from

https://www.google.com/url?sa=t\&source=web\&rct=j\&url=https://osf.io/q9b8f/download\& ved=2ahUKEwj1qci99fzvAhVHX30KHYLdCHg4FBAWMAF6BAgHEAI\&usg=AOvVaw1Qu52 WGtC6jHm3C3c-E2Dy (29 Mei 2021).

${ }^{5}$ Majid, Abdul dan Dian Andayani, Pendidikan Karakter Prespektif Islam, (Bandung: Rosda Karya 2012), hlm. 11.

${ }^{6}$ Hamka Abdul Aziz, Pendidikan Karakter Berpusat Pada Hati (Jakarta Selatan: AL-MAWARDI PRIMA,2012), hlm. 167.
} 
sembarang orang di luar bidang pendidikan. Untuk seorang Guru perlu mengetahui dan dapat menerapkan beberapa prinsip mengajar agar dapat melaksanakan tugasnya secara profesional. Dalam pengembangan karakter peserta didik di sekolah, guru memiliki posisi yang strategis sebagai pelaku utama. Guru merupakan sosok yang bisa ditiru atau menjadi idola bagi peserta didik. Guru bisa menjadi sumber inpirasi dan motivasi peserta didiknya. Sikap dan prilaku seorang guru sangat membekas dalam diri siswa, sehingga ucapan, karakter dan kepribadian guru menjadi cermin siswa. Dengan demikian guru memiliki tanggung jawab besar dalam menghasilkan generasi yang berkarakter, berbudaya, dan bermoral.

Dalam Undang-Undang Sistem Pendidikan Nasional diamanatkan bahwa seorang guru harus memiliki kepribadian yang baik. kepribadian tersebut menggambarkan sifat pribadi dari seorang guru. Satu yang penting dimiliki oleh seorang guru dalam rangka pengambangan karakter anak didik adalah guru harus mempunyai kepribadian yang baik dan terintegrasi dan mempunyai mental yang sehat. Profesi guru mempunyai 2 tugas penting, yaitu mengajar dan mendidik. Kedua tugas tersebut selalu mengiringi langkah sang guru baik pada saat menjalankan tugas maupun diluar tugas.

Tujuannya adalah untuk membentuk siswa agar menjadi insan kamil. Dengan pendidikan karakter diharapkan dapat membentuk watak yang berakhlak mulia. Pendidikan karakter tidak hanya sekedar membentuk peserta didik menjadi pribadi yang cerdas dan baik, melainkan juga membentuk mereka menjadi manusia yang baik bagi kehidupanya sendiri, yaitu menjadi seseorang yang memiliki jiwa keadilan, baik, dan kemanusiaan. Oleh sebab itu kami mengangkat judul tersebut kami berharap dapat memajukan dan menjadikan kita sebagai seorang pribadi yang berakhlak baik yang bernuansa tasawuf. Semoga dengan semua ini bisa membawa diri kita dan orang lain bisa menjadi manusia yang berakhlak. 


\section{METODE PENELITIAN}

Peneliti menggunakan metode penelitian kualitatif dengan jenis kajian kepustakaan. Metode kepustakaan adalah teknik pengumpulan data dengan mengadakan studi penelaahan buku-buku, literatur-literatur, catatan-catatan, dan laporan-laporan yang ada hubungannya dengan permasalahan yang menjadi obyek penelitian.

\section{HASIL DAN PEMBAHASAN}

\section{Peran Guru dalam Pendidikan Karakter Peserta Didik}

Guru adalah pendidik, yang menjadi tokoh, panutan, dan identifikasi bagi para peserta didik, dan lingkungannya. Oleh karena itu, guru harus memiliki standar kualitas pribadi tertentu, yang mencakup tanggung jawab, wibawa, mandiri, dan disiplin. Berkaitan dengan tanggung jawab; guru harus mengetahui, serta memahami nilai, norma moral, dan sosial, serta berusaha berperilaku dan berbuat sesuai dengan nilai dan norma tersebut. Guru juga harus bertanggung jawab terhadap segala tindakannya dalam pembelajaran di sekolah, dan dalam kehidupan bermasyarakat. Berkenaan dengan wibawa; guru harus memiliki kelebihan dalam merealisasikan nilai spiritual, emosional, moral, sosial, dan intelektual dalam pribadinya, serta memiliki kelebihan dalam pemahaman ilmu pengetahuan, teknologi, dan seni sesuai dengan bidang yang dikembangkan. ${ }^{7}$

Guru merupakan faktor yang sangat dominan dan paling penting dalam pendidikan formal pada umumnya karena bagi siswa guru sering dijadikan tokoh teladan, bahkan menjadi tokoh identifikasi diri. ${ }^{8}$ Guru merupakan salah satu unsur di bidang kependidikan harus berperan serta secara aktif dan menempatkan kedudukannya sebagai tenaga profesional

\footnotetext{
7 Imron Fauzi, Etika Profesi Keguruan, hlm. 80.

8 Cece Wijaya dan Tabrani Rusyan, Kemampuan Dasar Guru dalam Proses Belajar Mengajar (Bandung: PT Remaja Rosdakarya, 1994), hlm. 2.
} 
sesuai dengan tuntutan masyarakat yang semakin berkembang. ${ }^{9}$ Pendidikan karakter di sekolah sangat terkait dengan manajemen atau pengelolaan sekolah. Pengelolaan yang dimaksud adalah bagaimana pendidikan karakter direncanakan, dilaksanakan, dan dikendalikan dalam kegiatan-kegiatan. Pendidikan di sekolah secara memadai. Pengelolaan tersebut antara lain meliputi, nilai-nilai yang perlu ditanamkan, muatan kurikulum, pembelajaran, penilaian, pendidik dan tenaga kependidikan, dan komponen terkait lainnya. Dengan demikian, manajemen sekolah merupakan salah satu media yang efektif dalam pendidikan karakter di sekolah.

Pendidikan karakter bertujuan untuk meningkatkan mutu penyelenggaraan dan hasil pendidikan di sekolah yang mengarah pada pencapaian pembentukan karakter dan akhlak mulia peserta didik secara utuh, terpadu, dan seimbang, sesuai standar kompetensi lulusan. Melalui pendidikan karakter diharapkan siswa didik mampu secara mandiri meningkatkan dan menggunakan pengetahuannya, mengkaji dan menginternalisasi serta mempersonalisasi nilai-nilai karakter dan akhlak mulia sehingga terwujud dalam perilaku sehari-hari. Pendidikan karakter nantinya diharapkan menjadi budaya sekolah.

\section{Pengembangan Karakter}

Membentuk karakter tidak bisa dilakukan dalam sekejap dengan memberikan nasihat, perintah, atau instruksi, namun lebih dari hal tersebut. Pembentukan karakter memerlukan teladan, kesabaran, pembiasaan, dan pengulangan. Dengan demikian, proses pendidikan karakter merupakan proses pendidikan yang dialami oleh siswa sebagai bentuk pengalaman pembentukan kepribadian melalui mengalami sendiri nilai-nilai kehidupan, agama, dan moral.

Karakter setiap manusia terbentuk melalui 5 Tahap yang saling berkaitan. Lima tahapan itu adalah:

\footnotetext{
9 Sardiman, Interaksi dan Motivasi Belajar Mengajar (Jakarta: PT Raja Grafindo Persada, 2003), hlm. 125.
} 
a. Adanya nilai yang diserap seseorang dari berbagai sumber, seperti agama, ideologi, pendidikan dan lain-lain.

b. Nilai membentuk pola fikir seseorang yang secara keseluruhan keluar dalam bentuk rumusan visi.

c. Visi turun ke wilayah hati membentuk suasana jiwa yang secara keseluruhan membentuk mentalitas.

d. Mentalitas mengalir memasuki wilayah fisik dan melahirkan tindakan yang secara keseluruhan disebut sikap.

e. Sikap-sikap dominan dalam diri seseorang yang secara keseluruhan mencitrai dirinya adalah apa yang disebut sebagai karakter atau kepribadian.

Proses pembentukan mental tersebut menunjukan keterkaitan antara fikiran, perasaan dan tindakan. Dari akal terbentuk pola fikir, dari fisik terbentuk menjadi perilaku. Cara berfikir menjadi visi, cara merasa menjadi mental dan cara berprilaku menjadi karakter. Apabila hal ini terjadi terus menerus akan menjadi sebuah kebiasaan. ${ }^{10}$

Menurut Ratna Megawangi, pendiri Indonesia Heritage Foundation, ada tiga tahap pembentukan karakter, yakni:

a. Moral knowing: Memahamkan dengan baik pada anak tentang arti kebaikan. Mengapa harus berperilaku baik. Untuk apa berperilaku baik dan apa manfaat berperilaku baik.

b. Moral Feeling: Membangun kecintaan berperilaku baik pada anak yang akan menjadi sumber energi anak untuk berperilaku baik. Membentuk karakter adalah dengan cara menumbuhkannya.

c. Moral action: Bagaimana membuat pengetahuan moral menjadi tindakan nyata. Moral action ini merupakan outcome dari dua tahap sebelumnya dan harus dilakukan berulang-ulang agar menjadi moral behavior.

10 Abeecdick, 5 Tahap Pembentukan Karakter https://abeecdick.wordpress.com/2010/06/21/5tahap-pembentukan-karakter/ 
Dengan melalui tiga tahap tersebut, proses pembentukan karakter akan menjadi lebih mengena dan siswa akan berbuat baik karena dorongan internal dari dalam dirinya sendiri. ${ }^{11}$

Guru juga memiliki peran yang sangat vital dan fundamental dalam membimbing, mengarahkan, dan mendidik siswa dalam proses pembelajaran. Karena peran mereka yang sangat penting itu, keberadaan guru bahkan tak tergantikan oleh siapapun atau apapun sekalipun dengan teknologi canggih. Alat dan media pendidikan, sarana prasarana, multimedia dan teknologi hanyalah media atau alat yang hanya digunakan sebagai teachers' companion (sahabat-mitra guru).

Guru dapat mengembangkan karakter siswa dengan membuat kondisi yang nyaman dan menyenangkan bagi siswa untuk belajar sehingga karakter dapat terbangun melalui kegiatan pembelajaran. Guru memberi bimbingan, pemahaman, dan pengaruh. Siswa dapat menimati proses pembelajaran dengan senang hati.

Guru perlu mengembangkan nilai-nilai karakter, seperti kepedulian, kejujuran, keadilan, tanggung jawab, dan rasa hormat terhadap diri dan orang lain, serta ketekunan, etos kerja yang tinggi, dan kegigihan, sehingga guru memiliki karakter yang baik. Oleh karena itu, ketika guru harus membentuk siswa agar berkarakter kuat, guru itu sendiri sudah memilikinya, sehingga siswa dapat meneladani perilaku, sikap, dan etika guru yang dapat diamati dan dilihat siswa dalam kehidupan sehari-hari. Guru yang berkarakter adalah guru yang memiliki nilai dan keyakinan yang dilandasi hakikat dan tujuan pendidikan serta digunakan sebagai kekuatan moral dalam menjalankan tugasnya sebagai pendidik. Oleh karena itu, guru yang berkarakter kuat memiliki kemampuan mengajar, dan juga dapat menjadi teladan bagi siswanya. Jadi dalam membentuk siswa yang berkarakter kuat dan positif, guru haruslah memiliki karakter yang kuat pula. ${ }^{12}$

\footnotetext{
11 Hartati Widiastuti, Peran Guru Dalam Membentuk Siswa Berkarakter, hlm. 44.

12 Hartati Widiastuti, hlm. 51.
} 


\section{Pendidikan Tasawuf}

Pendidikan merupakan suatu pondasi yang berperan serta dalam berdirinya sebuah perubahan yang disebut dengan Bangsa. Keaslian (eksistensi) suatu bangsa ditentukan oleh karakter yang dimilikinya. Bangsa yang mempunyai karakter yang kuat dapat menjadikan sebuah bangsa yang bermartabat dan disegani oleh bangsa-bangsa lain seluruh dunia. Menjadi sebuah bangsa yang berkarakter sudah menjadikan tujuan utama bagi bangsa Indonesia. Maka dari ini selaras dengan Fungsi Pendidikan Nasional yang terdapat dalam UU No 20 Tahun 2003 tentang Sistem Pendidikan Nasional yaitu Pendidikan Nasional berfungsi mengembangkan kemampuan dalam membentuk watak serta peradaban bangsa yang bermatabat dalam rangka mencerdaskan kehidupan bangsa, bertujuan untuk meningkatnya potensi peserta didik agar bisa menjadi manusia yang beriman dan bertakwa kepada Tuhan Yang Maha Esa, berakhlak mulia, sehat, cakap, berilmu, mandiri, kreatif, dan menjadi warga negara yang bersosial, demokratis, dan bertanggung jawab. ${ }^{13}$

Pendidikan merupakan bagian yang tidak terpisahkan dari kebudayaan. Pendidikan harus bertumpu pada kebudayaan yang dinamis dan mengalami adaptasi secara berkesinambungan. Menurut Ki Hadjar Dewantar pendidikan dibangun dengan menetapkan nilai-nilai seperti kehalusan rasa, sopan santu dalam tutur kata, persaudaraan dan perbuatan sebagai patokannya. Dengan demikian kesadaran mengenai garis hidup bangsa dengan kekayaan khazanah budaya nenek moyangnya harus ditempatkan sebagai esensi yang mewarnai teori dan pratik pendidikan. ${ }^{14}$

Kata tasawuf dan sufi merupakan bentuk mashdar dari fi'il khumasi (kata kerja lima huruf) yang bermuara pada kata shawwafa, yang berarti labis al-shuf (dia telah memakai wol kasar), sebagaimana kata taqammasha dari

\footnotetext{
13 Muhammad Husnul Rofiq, Model Pembentukan Karakter Berbasis Tasawuf Akhlaqi, jurnal.stituwjombang.ac.id, hlm. 72.

${ }^{14}$ Ibid., hlm. 74.
} 
kata qamish (gamis). Shuf merupakan pakaian yang dikenakan oleh para pendahulu pengamal tasawuf, atau oleh mereka yang menempuh cara hidup wara', zuhud, takwa dan khalwat. Jenis pakaian ini menjadi pilihan utama bagi orang-orang yang menempuh jalan hidup menuju Allah, karena lebih sesuai dengan model atau gaya hidupn sederhana dan layak dalam konteks pendidikan spritual terutama karena berindikasikan sikap rendah hati (tawadhu).

Tasawuf jika ditinjau dari segi istilah, tampaknya memiliki kesulian tersendiri untuk memahaminya. Hal ini disebabkan, memiliki kesulitan tersendiri untuk memahaminya. Hal ini disebabkan, di antaranya karena terjadi perbedaan dalam cara memandang aktivitas-aktivitas para kaum sufi. Di samping itu, tasawuf merupakan pengalaman batin yang dialami oleh individu yang tentunya sangat bersifat personal.

Sedangkan Pengertian tasawuf menurut istilah atau terminologi pun diartikan secara variatif oleh para ahli sufi, berikut adalah pengertian tasawuf menurut para ahli,antara lain: Imam Ghozali dalam kitab Ihya' ulumuddin, Tasawuf adalah ilmu yang membahas cara-cara seseorang mendekatkan diri kepada Allah SWT. ${ }^{15}$ Tasawuf adalah sebuah kegiatan pembersih jiwa, mengisinya dengan sifat-sifat terpuji (tahalli), dan mendekatkan diri (taqarrub) serta berada di hadrhirat Allah. Tasawuf sebagaimana disebutkan dalam makna di atas, bertujuan untuk memperoleh hubungan langsung dan dekat dengan tuhan, secara langsung tanpa perantara. Dalam ajaran tasawuf seorang sufi ternyata tidak begitu saja dapat berada dekat dengan tuhan, melainkan terlebih dahulu ia harus menempuh berbagai latihan (riyadhah) tertentu. Misalnya, ia harus menempuh beberapa maqam (tahapan) yaitu disiplin keruhanian yang ditujukan oleh seorang calon sufi dalam bentuk

${ }^{15}$ Al-Ghazali Abu Hamid, Ihya` Ulum ad-Din, 4 ed., 1 vol. (Beirut Lebanon: Dar al-Kotob AlIlmiyah, 2010). 
berbagai pengalaman yang dirasakan dan diperoleh melalui usaha-usaha tertentu. ${ }^{16}$

Mengingat pendidikan tasawuf merupakan bagian yang tidak terpisahkan dari pendidikan Islam, maka pengertian pendidikan Islam perlu diketahui terlebih dahulu. Ibnu Qayyim sebagaimana yang dikutip Hasan Bin Ali Hasan al-Hijazy mengemukakan bahwa Tarbiyah (pendidikan Islam) adalah upaya membentuk, merawat, dan mengembangkan potensi manusia untuk menjadi manusia yang berakhlakul karimah yang mampu berperan untuk mengemban amanah dan tanggung jawab sebagai khalifah di bumi dan mampu menjalankan apa yang telah diamanati atau diwajibkan Allah atasnya berupa tugas peribadatan kepada-Nya, sehingga manusia tersebut bisa berjalan dibumi ini untuk menumbuhkembangkan semua nikmat yang telah dikaruniakan kepadanya dan bisa berbuat amar ma'ruf nahi mun'kar dalam rangka memakmurkan bumi yang menjadi tempat tinggalnya sementara.

Dari pengertian ini, pendidikan mempunyai tujuan mempersiapkan manusia yang mampu dan siap berperan sebagai khalifah di atas muka bumi, abid. Dalam kaitan tersebut, seseorang yang telah menerima pendidikan, pada gilirannya ia mempunyai kewajiban untuk mendidik anggota mereka dan masyarakat sekelilingnya, karena sesungguhnya pendidikan itu adalah mengambil dan memberi, bukan halnya hanya sekedar mengambil dan melakukan sendiri melainkan mengajarkan kembali kepada yang lainnya, dan yang paling penting kita harus mengetahui hakekat perbedaan itu, karna dari perbedaan itulah kita bisa belajar untuk introfeksi diri sendiri.

Menurut Yusuf Qardhawi, pendidikan Islam adalah pendidikan manusia seutuhmya, meliputi akal dan hatinya, rohani dan jasmaninya, akhlak dan keterampilannya. Menurut Hasan Langgulung, pendidikan Islam adalah proses penyiapan generasi muda untuk mengisi peranan, memindahkan pengetahuan dan nilai-nilai Islam yang diselaraskan dengan

16 Muhammad Iqbal Irham, Pembangunan Karakter Islam Perspektif Tasawuf (Jakarta: Kencana), hlm. 30 . 
fungsi manusia untuk beramal di dunia dan memetik hasilnya di akhirat. Sedangkan secara agak teknis, Endang Saefuddin Anshari memberikan pengertian pendidikan Islam adalah proses bimbingan (pimpinan, tuntunan, usulan) oleh subyek didik terhadap perkembangan jiwa (pikiran, perasaan, kemauan, intuisi, dan lain sebagainya) dan raga obyek didik dengan bahanbahan materi tertentu dan dengan alat perlengkapan yang ada ke arah terciptanya pribadi tertentu disertai evaluasi sesuai dengan ajaran Islam. ${ }^{17}$

Sebagian orang berpendapat bahwa ajaran tasawuf merupakan teori yang dimunculkan oleh semua salaf. Mereka menilai bahwa tasawuf tidak memilki sumber yang jelas. Pemahaman seperti inilah cenderung memisahkan ajaran taswuf dengan ajaran islam yang mereka kenal selama ini. Tasawuf bukanlah ajaran mistik yang mengarah kepaga klenik dan perdukunan. Selama ini orang awam menganggap bahwa belajar ilmu tasawuf akan menjadi manusia khos, mengerti hal-hal ghaib, dapat menyingkap takdir, bisa berhubungan dengan roh yang sudah mati dan sejuta cerita-cerita yang cenderung menyesatkan. Oleh karena itu pemahaman tentang ajaran tasawuf perlu diluruskan.

Satu-satunya manusia yang layak dan seharusnya kita jadikan contoh, panutan dan publik figur adalah Nabi Muhammad SAW, sebab beliau adalah satu-satunya manusia yang paling sempurna di muka bumi ini. Kesempurnaan Nabi, terutama yang terpencar dari akhlaknya ternyata telah diakui oleh semua kalangan, tidak hanya kaum muslimin pada saat itu tetapi juga kaum kuffar. Tidak hanya kawan, tetapi juga lawan, tidak hanya manusia tetapi bahkan Allah sendiri telah memujinya, "sesungguhnya engkau (Muhammad) berakhlak mulia ", demikian firman Allah.

Tasawuf dalam kategori pertama, seperti disebutkan sebelumnya, yakni yang berhubungan dengan perilakudan akhlak atau moral, pada hakikatnya bukanlah suatu ilmu, presepsi atau atau sekadar rumusan-

${ }^{17} \mathrm{Ibid}$, hlm. 75-76. 
rumusan teori an sich. Tasawuf dalam klasifikasikan ini merupakan usahausaha yang mengarah kepada pembinaan moral atau akhlak yang mulia. Dalam konteks ini tasawuf bukanlah merupakan rumusan atau kumpulan teori-teori belaka karena jika sekedar teori, maka ia dapat dicapai dengan mujahadah (kesungguhan dalam mencapai sesuatu). Tasawuf juga sekadar ilmu semata-mata sebab jika hanya sekadar ilmu pengetahuan, maka tentu tasawuf dapat dihasilkan dengan cara belajar. Tasawuf sesungguhnya adalah berakhlak dengan akhlak Allah yang tidak mungkin diperoleh atau diterima semata-mata dengan ilmu dan teori. Bertasawuf dalam konteks ini adalah menegakkan moral dalam bentuk ucapan, perbuatan, dan aktivitas keseharian. Moral tentu saja harus dimulai dari masing-masing individu, keluarga, masyarakat, dan akhirnya seluruh komponen bangsa. Para ulama sering kali mengingatkan bahwa kejayaan suatu bangsa sangat tergantung pada moral bangsa itu sendiri.

Akhlak dan moral adalah tindakan yang didasarkan pada nilai-nilai mutlak kebaikan. Timbulnya kesadaran berakhlak atau kesadaran bermoral serta keteguhan manusia terhadapnya adalah pangkal yang menetukan corak hidup manusia. Hidup bermoral dan setiap perbuatan bermoral adalah jawaban yang tepat terhadap terhadap kesadaran berakhlak. Sebaliknya, hidup yang tidak bermoral dan setiap pelanggaran adalah penentangan terhadap kesadaran itu sendiri. Kesadaran moral adalah kesadaran manusia tentang dirinya sendiri, di mana ia melihat dan merasakan dirinya sedang berhadapan dengan baik dan buruk. Di sinilah ia membedakan antara yang hak dan batil, yang halal dan haram, yang terang dan remang-remang, yang boleh dan tidak boleh dilakukan, meskipun ia sanggup untuk melakukannya. Pada waktu manusia di hadapkan pada pilihan baik dan buruk, maka kemanusiaannya dipertaruhkan. Jika ia memilih yang buruk, maka jadilah ia sebagai manusia yang "jahat". Namun apabila ia memilih yang baik maka hidupnya berada di jalan yang benar. Di sini manusia harus menginsafi benar bahwa tuntutan moral merupakan tuntutan yang mutlak yang tak dapat 
dielakkan, karena tuntutan itu bersumber dari dalam dirinya sendiri, dari hati nurani. ${ }^{18}$

Tasawuf bukanlah suatu ilmu yang berdiri sendiri. Tetapi satu kesatuan dalam ajaran islam yang tujuannya adalah pembentukan akhlak mulia, menjadikan manusia ma'rifat (arif dan bijaksana), mengantarkan seseorang dalam menjalankan ibadah sehingga ia mencapai pada tahan kebenran yang hakiki. Ia akan dapat merasakan kenikmatan beribadah karena jiwanya bisa merapat kepada al-Haq. Mengingat cakupan ajaran islam begitu luas dan kompleks, maka ulama kemudian menjadikan tasawuf sebagai bagian dari sebuah ilmu yang dikaji secara mendalam. Sehingga seolah-olah ia berdiri sendiri.

Nyatanya bahwa ilmu tasawuf semata-mata bertujan sebagai saran kesempurnaan ibadah itu menjadi benar-benar sebagai ibadah, maka seseorang harus memutuskan hubungan dengan selain Allah. Artinya, segala sesuatu itu disandarkan kepada Allah, jangan disandarkan kepada makhluk. Jangan berharap apa pun kepada manusia. Jalan yang ditempuh selain itu ialah seseorang harus hati-hati dalam menyikapi permainan hidup. Banyak permainan hidup yang membuat orang menjadi binasa. Harta benda dan kemewahan merupakan bagian dari permainan hidup yang pada umumnya justru mencelakakan pemiliknya. Dengan menempuh jalan sufi, diharapkan seseorang tidak diberdaya oleh harta benda tetapi dia yang mampu memanfaatkan harta bendanya sebagaimana yang dicontohkan Rasulullah. Bukankah Rasulullah memanfaatkan seluruh hartanya untuk sesuatu yang lebih bermanfaat bagi umat manusia, yaitu pengembangan dan perjuangan islam. Sekarang umat manusia di seluruh dunia menikmati hasil dari pengorbanannya itu. ${ }^{19}$

\section{KESIMPULAN}

\footnotetext{
18 Ibid., hlm. 60-64

19 Syekh Ibnu Jabr ar-Rummi, Mendaki Tangga Ma'rifat, t.tt. t.tp. hlm. 18.
} 
Pendidikan merupakan hal yang penting di era zaman sekarang, termasuk di era globalisasi yang berkembang semakin pesat. Pendidikan dapat membentuk seseorang menjadi orang yang berkualitas. Salah satu wadah untuk membentuk manusia agar mempunyai kualitas yang tinggi serta dapat mengembangkan potensi yang ada pada diri seseorang ialah dengan pendidikan. Guru adalah pendidik, yang menjadi tokoh, panutan, dan identifikasi bagi para peserta didik, dan lingkungannya.

Oleh karena itu, guru harus memiliki standar kualitas pribadi tertentu, yang mencakup tanggung jawab, wibawa, mandiri, dan disiplin. Berkaitan dengan tanggung jawab; guru harus mengetahui, serta memahami nilai, norma moral, dan sosial, serta berusaha berperilaku dan berbuat sesuai dengan nilai dan norma tersebut. Tasawuf adalah bagian dari ajaran islam yang bertujuan agar seseorang tekun beribadah dan memutuskan hubungan dengan selain Allah, hanya menghadap Allah semata, menolak hiasan-hiasan duniawi, serta membenci ssesuatu yang memperdaya manusia, kenikmatan harta benda dan kemewahannya, dan menyendiri menuju jalan Allah dalam khalwat dan ibadah.

Pengertian tasawuf dapatlah disederhanakan, yaitu bertujuan untuk menyucikan jiwa dan pendekatan diri kepada Allah swt. Dua hal ini tidak bisa dipisahkan. Jika dijabarkan secara tereperinci, maka lahirlah apa yang disebut sebagai teori atau ajaran tasawuf. Bertasawuf dalam konteks ini adalah menegakkan moral dalam bentuk ucapan, perbuatan, dan aktivitas keseharian. Moral tentu saja harus dimulai dari masing-masing individu, keluarga, masyarakat, dan akhirnya seluruh komponen bangsa. Para ulama sering kali mengingatkan bahwa kejayaan suatu bangsa sangat tergantung pada moral bangsa itu sendiri.

\section{DAFTAR PUSTAKA}

Abeecdick, 5 Tahap Pembentukan Karakter https://abeecdick.wordpress.com/ 2010/06/21/5-tahap-pembentukan-karakter/ 
Ar-Rummi, Syekh Ibnu Jabr. Mendaki Tangga Ma'rifat, t,tt. t,tp.

Aziz, Hamka Abdul. Pendidikan Karakter Berpusat Pada Hati. Jakarta Selatan: ALMAWARDI PRIMA, 2012.

Hamid, Al-Ghazali Abu. Ihya` Ulum ad-Din, 4 ed., 1 vol. Beirut Lebanon: Dar alKotob Al-Ilmiyah, 2010.

Irham, Muhammad Iqbal. Pembangunan Karakter Islam Perspektif Tasawuf. Jakarta: Kencana, tt.

Kuswanto, Edi. Peranan Guru PAI dalam Pendidikan Akhlak di Sekolah, t.tt. t.tp.

Majid, Abdul dan Dian Andayani. Pendidikan Karakter Prespektif Islam. Bandung: Rosda Karya, 2012.

Rofiq, Muhammad Husnul. Model Pembentukan Karakter Berbasis Tasawuf Akhlaqi, jurnal.stituwjombang.ac.id.

Sardiman. Interaksi dan Motivasi Belajar Mengajar. Jakarta: PT Raja Grafindo Persada, 2003.

Seketariat Negara RI, Undang-undang No. 20 Tahun 2003, Tentang Sistem Pendidikan Nasional, pasal 3.

Sekretariat Negara RI, Undang-undang No. 20 Tahun 2003, Tentang Sistem Pendidikan Nasional, pasal ayat 1 , ayat 1 .

Sudrajat, Akhmad. Pengembangan karakter. Retrieved from https:/ / www.google.com/url?sa=t\&source=web\&rct=j\&url=https:/ / osf .io/q9b8f/ download\&ved=2ahUKEwj1qci99fzvAhVHX30KHYLdCHg4F BAWMAF6BAgHEAI\&usg=AOvVaw1Qu52WGtC6jHm3C3c-E2Dy Mei 2021)

Wijaya, Cece dan Tabrani Rusyan. Kemampuan Dasar Guru dalam Proses Belajar Mengajar. Bandung: PT Remaja Rosdakarya, 1994. 